\title{
Theatre and the Anthropocene Introduction
}

\section{S.E. WILMER \& KAREN VEDEL}

The Anthropocene has been defined as the present geological epoch in which the earth's ecosystems and biodiversity are being slowly disrupted by human intervention. The term has gained popularity from 2002 when Paul Crutzen argued its importance in a Nature article, and since then scientists have debated its credibility and possible starting point, suggesting various dates such as 10,000 years ago (at the beginning of agricultural societies and deforestation), or around 1600 (at the beginning of the plantation and slavery period) or the end of the eighteenth century (with the birth of the industrial revolution) or 1945 (with the commencement of nuclear weapons testing).

The notion of the Anthropocene raises important questions concerning the sustainability of the planet. The seas have been slowly rising and becoming inexorably contaminated. Fish life, plankton, and coral reefs have been dying because of climate change and pollution from plastic, oil, and other forms of human waste. Millions of animal species have become endangered or extinct. Huge tracts of land in Africa have been leased by China to feed its own population. African governments have been encouraging their citizens to go abroad in order to send back foreign income to sustain their national economies. Aggressive mining operations, fertilization, and over-cultivation of land are destroying habitats, resulting in a devastating loss of bio-diversity. The ubiquitous burning of fossil fuels and the increase in carbon dioxide in the atmosphere have resulted in climate change. Deforestation, drought, desertification, poverty and hunger in the global south are forcing waves of migration. Periodic oil disasters and emissions of radiation from nuclear power plants as well as the continual threat of nuclear war, and the rapid increase of the world population to 7 billion (estimated to increase to 10 billion by 2050) all raise questions about the sustainability of the human much less the animal 
population. Elon Musk has offered a wake-up call by proposing that we need to colonize Mars.

Posthumanism has offered an alternative to anthropocentrism, emphasising the importance of the non-human in the challenge against the destructive effects of the Anthropocene. Posthumanism privileges animals, plant life, ecological systems, and the environment, as well as providing a feminist perspective on human patriarchy. It promotes the protection and conservation of the earth and its inhabitants, recognizing continuity between all living creatures including plants, animals, and humans. Other recent trends in philosophy offer new materialism, object-oriented ontologies, and theories of social assemblage as ways to understand the Anthropocene.

There has been increasing interest in the Anthropocene from cultural theorists such as Donna Haraway, Bruno Latour, Rosi Braidotti, Bernard Stiegler, Cary Wolfe, Karen Barad, Jussi Parikka, Elizabeth Grosz, Stacy Alaimo, T.J. Demos, Nicholas Mirzoeff, Anna Tsing, Saskia Sassen, Jason W. Moore, and Timothy Morton. In the emerging field of ecology and theatre, Una Chaudhuri has been one of the early pioneers along with Bonnie Marranca, Baz Kershaw, Wendy Arons, and Theresa J. May. Many of them have critiqued the term Anthropocene, renaming it, for example, Chthulucene (Haraway), White Supremacy Scene (Mirzoeff), Anthrobscene (Parikka), Capitalocene (Moore), or Neganthropocene (Stiegler). However, despite these critiques, the term Anthropocene still resounds as a call for attention to an urgent situation.

In this issue of Nordic Theatre Studies, theatre and performance scholars offer a variety of approaches that attest to the importance of the Anthropocene in Nordic and Baltic countries. In the opening essay, Teemu Paavolainen provides a historical and sociological interpretation of the Anthropocene, employing Lewis and Maslin's recent book The Human Planet: How We Created the Anthropocene as a guide. Using a performance theory lens, Paavolainen demonstrates that the Anthropocene has resulted from the repetitive behaviour over hundreds of years of different forms of activity, which the elites in society have forced on the majority of the population. Through the repetition of such actions as clearing the land, marketing cash crops, and developing various capitalist enterprises, such practices have become normative and their deleterious effects less noticeable. Paavolainen regards the present dangers to the planet as critical and suggests that the latest threat from fossil capitalism could be defeated by a sustained social rebellion of at least 3.5 per cent of the population.

The next five articles examine theatre performances about ecological issues. Audronè Žukauskaitè takes a posthumanist approach to a film and an opera, the latter being the outstanding success at last year's Venice Biennale. Employing the theories of Foucault and Agamben about biopolitics and bare life, Žukauskaitè points out the importance of visuality in determining power. Adapting Nicholas Mirzoeff's notion of counter-visuality, Žukauskaitè proposes a theory of "not-quite-human visuality" that reverses the notion of the panopticon and helps identify everyone as being subjected to the effects of the Anthropocene. In Acid Forest, a documentary on cormorants directed by Rugile Barzdžiukaitè, the camera takes the perspective of the cormorants at the top of 
the trees looking down on humans who are visiting a viewing site. In Sun and Sea (by Rugilè Barzdžiukaitè, Vaiva Grainytè and Lina Lapelytė), which Bruno Latour termed "the New Climatic Regime", 1 the spectators stare down from a gallery at performers singing, while sun-bathing on a beach. Žukauskaitè demonstrates that the normal perspective and the power dynamic have shifted to a not-quite-human one, as the human audience recognise that they are equally an endangered species.

Kim Skjoldager-Nielsen and Daria S. Nielsen also consider two performances that focus on environmental change as exemplars of a para-Anthropocene aesthetic: Hotel Pro Forma's visual electro-opera NeoArctic: 12 Soundscapes. 12 Landscapes. 1 Planet (2016) and Yggdrasil Dance's Siku Aapoq/Melting Ice (2015). NeoArctic projects images onto a choir whose costumes combine Inuit anoraks with modern raincoats, creating a ghostly presence, while Siku Aapoq/Melting Ice features two dancers amidst vanishing glaciers, with both performances conveying simultaneously a sense of the past, present, and future. Applying Karen Barad's theory of "agential realism" to these performances that testify to the material changes in Nordic and Arctic climates, the SkjoldagerNielsens question the effect on the audience. They suggest that Barad's theory of response-ability for the human and the non-human is apposite in determining the impact of such "dystopian" theatre on an audience, regarding the pieces as activist in presenting a "nightmare hoping for change".

Nassim Balestrini also discusses changes in the Arctic climate in two performances from an emerging Arctic Cycle of plays. The playwright Chantal Bilodeau is planning to feature eight different nations in the Arctic territory, with the first two, Sila and Forward, focusing on Canada and Norway respectively. Both plays depict ice as a force of nature that can overcome human endeavours: through its changing structure in Sila and as a metaphysical character who confronts a Norwegian explorer in Forward. Bilodeau's works serve both as a warning about environmental damage (especially through the Norwegian oil industry), and as an effort to reclaim indigenous cultures. Balestrini demonstrates how both pieces employ sonic effects to convey a pluriversal perspective incorporating both Inuit and western values, languages, and music.

By contrast with these articles that address recent artistic works concerning ecological damage, Erik Mattsson's article investigates a largely forgotten mass spectacle in the 1970's about the dangers of nuclear power. Eko-positivet was an open-air event with a cast of 300-400 for an audience of about 8,000 in Gothenburg and 4,000 in Stockholm, making it, according to Mattsson, "one of the largest theatrical events in Swedish history". Nevertheless, by contrast with $\mathrm{Vi}$ äro tusenden, a well-known contemporary political performance about the history of the Swedish working class, Eko-positivet was largely ignored by the left-wing press, the independent theatres, and theatre historians. Mattsson argues that, despite journalists regarding it as a novel form of street theatre that had rarely been seen in Sweden, Eko-positivet was ignored because

1 https://www.evensi.it/speaking-beach-conversation-bruno-latour-marina-lithuanian-pavilion58th-venice-biennale/317369122, accessed 1 April 2020. 
its political agenda did not coincide with the class-based politics of other independent theatre companies. While the performance did not tap into the hegemonic political discourse of the day, it marked an important shift from radical class politics to an alternative movement incorporating diverse causes such as women's, LGBT, and disability rights as well as environmental issues. Mattsson suggests that the performance achieved what Mouffe and Laclau have termed "the need to create a chain of equivalence among the various democratic struggles."

Focusing on theoretical and dramaturgical concerns that occur in theatre for the early years (TEY), the article by Lise Hovik and Elena Pérez considers the process of their creation of Baby Becomings. As part of their ongoing artistic research on "performative aspects of posthumanism within an established postdramatic dramaturgy of baby theatre", Hovik and Pérez present the artistic and philosophical inspiration from Donna Haraway's notion of sympoietic science art worlding and its connection to Deleuze \& Guattari's thinking on becoming and the rhizome. In pursuit of a dramaturgy of decentred works that integrate different art forms and multiple materialities in a non-hierarchical manner, the article explores the ongoing rhizomatic transformations of Baby Becomings as a characteristic of the work. Once more Barad's notion of "agential realism" is engaged, this time in a discussion of the ways in which Baby Becomings offers the babies an entanglement with the material world, its human and non-human beings. In conjunction with a discussion of various postdramatic approaches, the research leads the authors to propose a dramaturgy of sympoietic worldings as a useful framework in theatre for young children where a narrative logic is replaced by co-creation and a transformational logic of material, movement, and musical elements.

The final three articles move the journal issue into other forms of media: video, computer games, and printed matter. In discussing her project on "performing with plants", Annette Arlander invokes Rosi Braidotti's four theses for a posthuman feminism: "feminism is not a humanism", "anthropos is offcenter", "zoe is the ruling principle", and "sexuality is a force beyond gender". Arlander assesses the usefulness of these theses in reviewing performances with other-than-human entities and especially with regard to her own artistic research project. With a video camera mounted on a tripod, she recorded herself sitting (with her back to the camera) on two tree stumps over the course of a year and then edited the footage into time-lapse videos. She assesses her performance as well as that of the plants during the seasonal changes, and, although there were "no exchanges of mutual benefit taking place comparable to gardening", she concludes that performing with plants might "mitigate the anthropocentrism of performance art".

Like Arlander, Vlad Butucea also invokes Braidotti in his examination of an ecologically-themed computer game called Everything. Using Braidotti's notion of nomadism that is derived from Deleuze and Guattari, Butucea argues that the game, which enables the player to inhabit non-human avatars to gain a wider perspective on the earth, encourages a new way of thinking and provides a "platform for self-expression". Butucea also employs Audronè Žukauskaitè's 
notion of "nomadic performativity", which appeared in an earlier issue of Nordic Theatre Studies, as a framework to examine various dimensions of the game. He suggests that the game is a form of interactive theatre in which the player can serve as playwright, director, and actor, and the game can also go into auto-mode, which enables its Artificial Intelligence to progress the game when the player becomes inactive. Through the player's experimentation with various non-human avatars such as animals, rocks, and plants, the game acts as a "perfect enactment of nomadic performativity", providing a critique of human domination and responsibility for the Anthropocene.

Writing in an inventive style that is somewhat reminiscent of Deleuze and Guattari's Thousand Plateaus, but using the metaphor of tectonic plates rather than plateaus, Carl Lavery reflects on Mémoires, a book by Guy Debord and Asger Jorn from 1958. Mémoires was a Situationist publication that used a collage of found objects, images, splotches of colour, and fragments of text as an experiment in typography and spatial disruption on the page. Lavery suggests that the book evokes a sense of dérive or drift, "allowing the text to drift, to become theatrical." Regarding it as an "exercise in psychogeology", Lavery suggests that it conveys "what it means to live on a planet in constant movement". Both Mémoires and Lavery's eccentric writing style can be seen as ecological performances.

These articles, which treat the Anthropocene from widely different perspectives, provide a valuable introduction to the types of approaches and the range of performances and media that can be deployed to address this urgent topic. While it is taking second place in people's minds to the Covid-19 virus at the moment, the threat to the environment will continue and will need to be addressed. As Bruno Latour has written, contrasting the threat of the virus with the environmental crisis, "In the health crisis, it may be true that humans as a whole are 'fighting' against viruses... The situation is tragically reversed in ecological change: this time, the pathogen whose terrible virulence has changed the living conditions of all the inhabitants of the planet is not the virus at all, it is humanity!"2 And as Achille Mbembe writes, "If, indeed, Covid-19 is the spectacular expression of the planetary impasse in which humanity finds itself today, then it is a matter of no less than reconstructing a habitable Earth to give all of us the breath of life. We must reclaim the lungs of our world with a view to forging new ground. Humankind and biosphere are one. Alone, humanity has no future." ${ }^{3}$ Like the current pandemic, the climate crisis unites the world and endangers us all.

\footnotetext{
2 Bruno Latour (2020), "Is this a Dress Rehearsal?", Critical Inquiry, 26 March. https://critinq. wordpress.com/2020/03/26/is-this-a-dress-rehearsal/?fbclid=IwAROUbKyYnfcb1kWl1tAYrhLNjH wnqFG6bsKYzc4g1i2Vweszja5wlmxY2QA, accessed 1 April 2020.

3 Achille Mbembe (2020), "The Universal Right to Breathe", trans. Carolyn Shread, Critical Inquiry, April 13. https://critinq.wordpress.com/2020/04/13/the-universal-right-to-breathe/, accessed 15 April 2020.
} 